\title{
A RADIOMIMETIC EFFECT OF HYDROGEN PEROXIDE ON BACTERIAL LUMINESCENCE
}

\author{
A. P. JACOBSON and K. A. McDERMOTT
}

Department of Environmental and Industrial Health, The University of Michigan, Ann Arbor, Michigan 48104, U.S.A.

Received 17 November 1970; revised manuscript received 24 January 1971

Hydrogen peroxide $\left(\mathrm{H}_{2} \mathrm{O}_{2}\right)$ in appropriate doses was found to mimic the reversible X-ray suppression of bacterial luminescence. Catalase protected against this suppression both by X-rays and $\mathrm{H}_{2} \mathrm{O}_{2}$, but albumin did not. Luminescence did not recover until $\mathrm{H}_{2} \mathrm{O}_{2}$ was destroyed. These results support our hypothesis that reduced intermediates of the luminescent pathway are reversibly oxidized by both $\mathrm{X}$-rays and $\mathrm{H}_{2} \mathrm{O}_{2}$. Cyanide enhanced the effects of both $\mathrm{X}$-rays and $\mathrm{H}_{2} \mathrm{O}_{2}$ and this result suggests that endogenous catalase is important to the survival of cells exposed to ionizing radiation.

\section{Introduction}

Radiation immediately suppresses bacterial luminescence to a lowered steady state. After irradiation, luminescence recovers within minutes to a new steady state ${ }^{1,2}$ ). See fig. 1 . At least a part of this effect could be due to

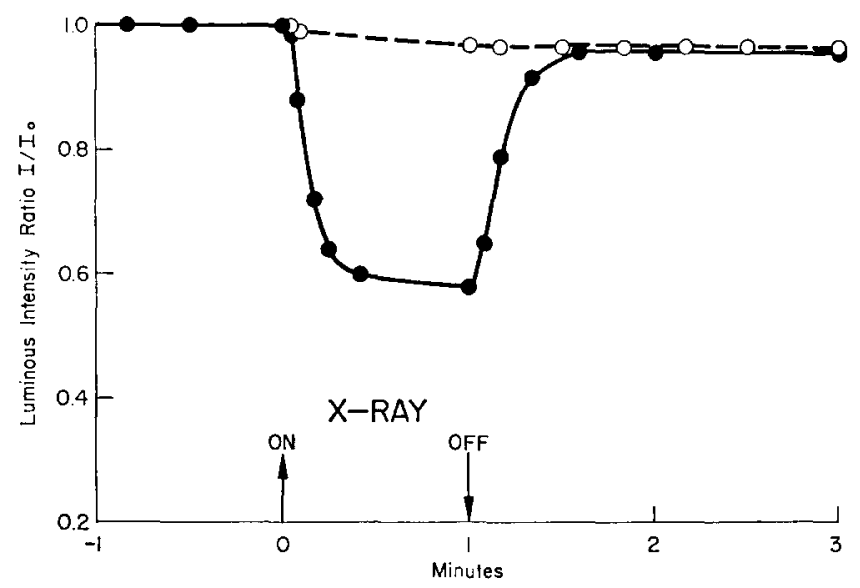

Fig. 1. The reversible suppression of bacterial luminescence by $\mathrm{X}$-rays ${ }^{1,2}$ ). Solid curve: no catalase. Dashed curve: 100 Sigma Units of catalase added before irradiation. For these experiments, bacterial cells were suspended in buffered saline at $23.0 \pm 0.3^{\circ} \mathrm{C}$. The X-ray dose rate was $6500 \mathrm{rad} / \mathrm{min}$. 
hydrogen peroxide $\left(\mathrm{H}_{2} \mathrm{O}_{2}\right)$ formed as a product of water radiolysis $\left.{ }^{3-7}\right)$. The dashed curve of fig. 1 shows the protective effect of catalase added to bacterial samples prior to $X$ irradiation. Since most cells contain catalase ${ }^{8}$ ), it is not surprising that most attempts to imitate radiation injury by the addition of $\mathrm{H}_{2} \mathrm{O}_{2}$ have not been successful ${ }^{9}$ ). However, some studies have been successful (for examples, refs. 10 and 11).

This study describes how $\mathrm{H}_{2} \mathrm{O}_{2}$ mimics the immediate, reversible, X-ray suppression of bacterial luminescence in doses analogous to $\mathrm{X}$-ray doses from $2 \times 10^{3}$ to $2 \times 10^{5} \mathrm{rad}^{12}$ ).

\section{Methods and materials}

Photobacterium fischeri were washed free of nutrient material, centrifuged, re-suspended in $3 \mathrm{ml}$ of non-nutrient, buffered saline $\left(10^{-1} \mathrm{M}, \mathrm{pH} 7.2\right)$ at $2 \times 10^{9}$ cells per milliliter, and stored at $4^{\circ} \mathrm{C}$ until used. Details of sample preparation have been reported ${ }^{13}$ ).

The photometer for measuring luminescence has been described ${ }^{13}$ ). The waterbath at $12^{\circ} \mathrm{C}$ surrounded the photometer housing and ensured adequate temperature control of samples during, as well as before, experiments.

To begin an experiment, a luminous sample was placed in the photometer and allowed to reach $12^{\circ} \mathrm{C}$. After initial measurements of luminous intensity and stability, $10 \mu \mathrm{l}$ of $\mathrm{H}_{2} \mathrm{O}_{2}$ at various concentrations were added to the sample. To ensure rapid mixing of $\mathrm{H}_{2} \mathrm{O}_{2}$ with cells, the following procedure was devised: First, a $15 \mathrm{~cm}, 20$ gauge needle was inserted through a hole in the photometer until it rested on the bottom of the test tube in front of the photocathode. Ten $\mu \mathrm{l}$ of $\mathrm{H}_{2} \mathrm{O}_{2}$ were placed in the needle's breech. Next, a 1 $\mathrm{ml}$ syringe was fitted to the breech and some sample medium was drawn quickly into the syringe. The mixture was moved rapidly into and out of the syringe three times to ensure prompt and thorough mixing. Suppression of luminescence began immediately.

Since it was desirable to know whether luminescence recovered in the presence of $\mathrm{H}_{2} \mathrm{O}_{2}$ by some process of adaptation or only after $\mathrm{H}_{2} \mathrm{O}_{2}$ was destroyed by hydrolysis, experiments were designed to measure residual $\mathrm{H}_{2} \mathrm{O}_{2}$ at various times after addition. These values were then compared to the time-course of luminescence after $\mathrm{H}_{2} \mathrm{O}_{2}$ addition. A modification of the method of Savage ${ }^{14}$ ) was used for measurements of $\mathrm{H}_{2} \mathrm{O}_{2}:$ a $6 \mathrm{ml}$ sample of luminous bacteria was treated with $10 \mu \mathrm{l}$ of $8.8 \times 10^{-2} \mathrm{M} \mathrm{H}_{2} \mathrm{O}_{2}$ (final concentration $1.5 \times 10^{-4} \mathrm{M}$ ) and a timer started. At various intervals after addition, this mixture was pulled into a syringe, then the syringe was fitted with a filter of $0.65 \mu \mathrm{m}$ pore size, and $4 \mathrm{ml}$ of sample were filtered into a test tube. The timer was stopped here to measure contact time between $\mathrm{H}_{2} \mathrm{O}_{2}$ 
and cells. To this filtrate, $0.4 \mathrm{ml}$ of $0.001 \mathrm{M}$ ammonium molybdate in $1 \mathrm{~N}$ $\mathrm{H}_{2} \mathrm{SO}_{2}, 0.4 \mathrm{ml}$ of a $5 \%$ starch solution, and $0.4 \mathrm{ml}$ of $1 \mathrm{M}$ potassium iodide were added. Color was allowed to develop for $10 \mathrm{~min}$ and the sample was read at $600 \mathrm{~nm}$ in a Beckman DU spectrophotometer.

Catalase activity was assayed by the Sigma method and is reported in Sigma units $(\mathrm{SU})^{15}$ ). Purity of reagent $\mathrm{H}_{2} \mathrm{O}_{2}$ was assayed with potassium permanganate ${ }^{16}$ ).

\section{Results}

Various measurements from the luminescence curves useful for analysis are: initial luminescence, the luminous intensity immediately prior to treatment; maximum suppression, the lowest point reached by luminescence after

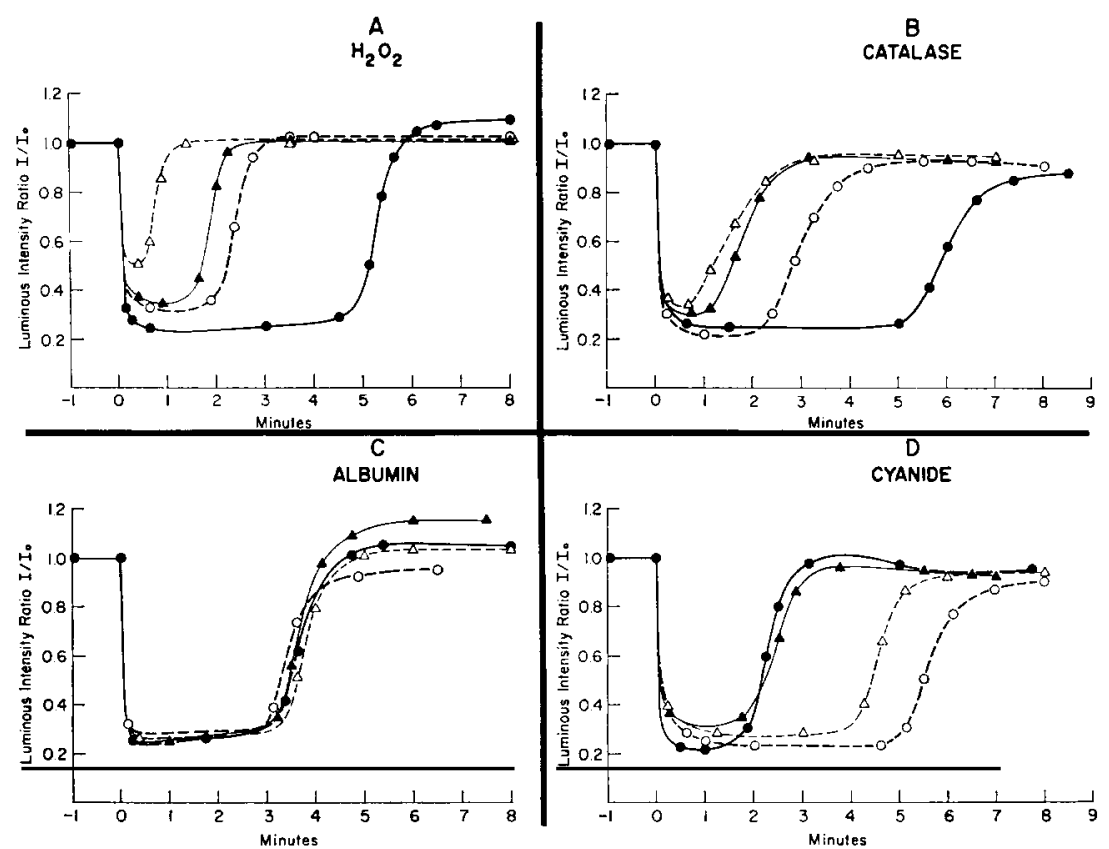

Fig. 2. The reversible suppression of bacterial luminescence by $\mathrm{H}_{2} \mathrm{O}_{2} \cdot \mathrm{H}_{2} \mathrm{O}_{2}$ was added at $0 \mathrm{~min}$. All other reagents were added previous to the addition of peroxide:

(A) $\mathrm{H}_{2} \mathrm{O}_{2}$ alone, $2.9 \times 10^{-4} \mathrm{M} \mathrm{H}_{2} \mathrm{O}_{2}, 02.9 \times 10^{-5} \mathrm{M} \mathrm{H}_{2} \mathrm{O}_{2}, \triangle 1.5 \times 10^{-5} \mathrm{M} \mathrm{H}_{2} \mathrm{O}_{2}$ $\triangle 2.9 \times 10^{-6} \mathrm{M} \mathrm{H}_{2} \mathrm{O}_{2}$;

(B) $2.9 \times 10^{-4} \mathrm{M} \mathrm{H}_{2} \mathrm{O}_{2}$ plus catalase, no catalase, $09.3 \mathrm{~S} . \mathrm{U}$. catalase, $456 \mathrm{~S} . \mathrm{U}$. catalase, $\triangle 112$ SU catalase;

(C) $2.9 \times 10^{-4} \mathrm{M} \mathrm{H}_{2} \mathrm{O}_{2}$ plus albumin, no albumin, $00.1 \mathrm{mg} / \mathrm{ml}$ albumin, $\Delta 0.2 \mathrm{mg} / \mathrm{ml}$ albumin, $\triangle 0.4 \mathrm{mg} / \mathrm{ml}$ albumin;

(D) $2.9 \times 10^{-5} \mathrm{M} \mathrm{H}_{2} \mathrm{O}_{2}$ plus $\mathrm{KCN}, \bullet$ no cyanide, $\triangle 3.33 \times 10^{-5} \mathrm{M} \mathrm{KCN}, \triangle 1.67 \times 10^{-4}$ $\mathrm{M} \mathrm{KCN}, 03.33 \times 10^{-4} \mathrm{M} \mathrm{KCN}$. 
treatment; maximum recovery, the maximum luminous intensity achieved after treatment; and recovery-half-time $\left(R T_{\frac{1}{2}}\right)$, the time after treatment where luminescence regains $\frac{1}{2}$ the value between maximum suppression and maximum recovery.

Fig. 2A shows the effects of adding $\mathrm{H}_{2} \mathrm{O}_{2}$ to luminous cell samples in the range from $2.9 \times 10^{-4} \mathrm{M}$ to $2.9 \times 10^{-6} \mathrm{M}$ final concentration. The effect produced by $\mathrm{H}_{2} \mathrm{O}_{2}$ was strikingly similar to that produced by $X$ rays (refs. 1,2 and fig. 1). With $\mathrm{X}$ rays the level of suppression depends upon the dose rate while the duration of suppression depends on total dose ${ }^{1}$ ). Changes of $\mathrm{H}_{2} \mathrm{O}_{2}$ concentration produced marked changes on the level of suppression and on the recovery half time. Neither the initial rate of suppression nor the rate of recovery were significantly changed by altering the $\mathrm{H}_{2} \mathrm{O}_{2}$ concentration. At $2.9 \times 10^{-4} \mathrm{M} \mathrm{H}_{2} \mathrm{O}_{2}$, luminescence after recovery exceeded the initial value. Lesser concentrations than this produce little or no such "stimulation" and, in fact, sometimes inhibit full recovery (fig. 2A). No effects were observed after $10 \mu \mathrm{l}$ additions of buffered saline or distilled water.

It was postulated that these effects from $X$ rays and $\mathrm{H}_{2} \mathrm{O}_{2}$ were produced by chemical oxidations and that catalase added to cell samples before treatment should diminish or eliminate such effects. Fig. 2B illustrates the changes in the basic response of luminescence to $2.9 \times 10^{-4} \mathrm{M} \mathrm{H}_{2} \mathrm{O}_{2}$ by the addition of catalase. Concentrations of catalase greater than $168 \mathrm{SU}$ were not studied since they produce turbidity and dim luminescence. In contrast to increased amounts of $\mathrm{H}_{2} \mathrm{O}_{2}$, the addition of catalase markedly shortened $R T_{\frac{1}{2}}$. Neither the rate of suppression nor recovery were changed significantly.

There is some variability in the amount of response to $\mathrm{H}_{2} \mathrm{O}_{2}$ between different batches of bacteria, but comparisons between batches are valid since the response to $\mathrm{H}_{2} \mathrm{O}_{2}$ is measured for each batch before other reagents are studied. The effects of these reagents are then compared to the basic response produced by $\mathrm{H}_{2} \mathrm{O}_{2}$ alone.

If the attenuated effects of $\mathrm{H}_{2} \mathrm{O}_{2}$ produced by catalase (fig. 2B) were produced by specific catalytic lysis of $\mathrm{H}_{2} \mathrm{O}_{2}$ and not simply by reaction with catalase protein, albumin in weights equivalent to the weight of catalase added should not change the basic response. No significant difference was found between samples treated only with $2.9 \times 10^{-4}$ or with albumin plus this amount of peroxide (fig. $2 \mathrm{C}$ ).

Catalase activity is poisoned by cyanide which inhibits reduction of the ferric ions by $\mathrm{H}_{2} \mathrm{O}_{2}{ }^{17}$ ). To study whether the action of $\mathrm{H}_{2} \mathrm{O}_{2}$ on luminescence could be modified by endogenous catalase, $\mathrm{KCN}$ was added to luminous samples in the range from $3.33 \times 10^{-4} \mathrm{M}$ to $3.33 \times 10^{-5} \mathrm{M}$ final concentration. Again, $R T_{\frac{1}{2}}$ was altered more than other luminescent characteristics (fig. 2D). The rate of recovery was slightly reduced in the cyanide-treated 
samples and the time required for luminescence to reach the lowest point was lengthened. The data are summarized in table 1.

The experiments summarized by fig. 3 show that luminescence recovered only after $\mathrm{H}_{2} \mathrm{O}_{2}$ concentration diminished considerably. Some slight re-

\section{TABLE 1}

A summary of the effect of various treatments on bacterial luminescence with standard errors

\begin{tabular}{|c|c|c|c|}
\hline Treatment & Concentration & $\begin{array}{c}\text { Percent } \\
\text { suppression }\end{array}$ & $\begin{array}{l}R T_{\frac{1}{2}} \\
\left(\mathrm{~min}^{2}\right)\end{array}$ \\
\hline $\mathrm{H}_{2} \mathrm{O}_{2}$ & $\begin{array}{l}2.9 \times 10^{-6} \mathrm{M} \\
1.5 \times 10^{-5} \mathrm{M} \\
2.9 \times 10^{-5} \mathrm{M} \\
2.9 \times 10^{-4} \mathrm{M}\end{array}$ & $\begin{array}{l}46.0 \pm 5.0 \\
66.4 \pm 1.3 \\
69.7 \pm 3.6 \\
76.3 \pm 5.9\end{array}$ & $\begin{array}{l}0.73+0.19 \\
1.98+0.24 \\
2.66 \pm 0.39 \\
5.06 \pm 1.09\end{array}$ \\
\hline Catalase $+2.9 \times 10^{-4} \mathrm{M} \mathrm{H}_{2} \mathrm{O}_{2}$ & $\begin{array}{r}19 \text { units } / \mathrm{ml} \\
56 \text { units } / \mathrm{ml} \\
112 \text { units } / \mathrm{ml} \\
168 \text { units } / \mathrm{ml}\end{array}$ & $\begin{array}{l}68.5 \pm 4.9 \\
68.0 \pm 4.7 \\
63.5 \pm 6.4 \\
59.8 \pm 7.2\end{array}$ & $\begin{array}{l}1.92 \pm 0.27 \\
1.47 \pm 0.35 \\
1.02 \pm 0.43 \\
0.75 \pm 0.19\end{array}$ \\
\hline Albumin $+2.9 \times 10^{-4} \mathrm{M} \mathrm{H}_{2} \mathrm{O}_{2}$ & $\begin{array}{l}0.1 \mathrm{mg} / \mathrm{ml} \\
0.2 \mathrm{mg} / \mathrm{ml} \\
0.3 \mathrm{mg} / \mathrm{ml} \\
0.4 \mathrm{mg} / \mathrm{ml}\end{array}$ & $\begin{array}{l}72.2 \pm 0.8 \\
74.7+0.6 \\
73.5+1.5 \\
74.8 \pm 0.7\end{array}$ & $\begin{array}{l}3.66 \pm 0.26 \\
3.94 \pm 0.18 \\
3.98 \pm 0.50 \\
4.00 \pm 0.60\end{array}$ \\
\hline $\mathrm{KCN}+2.9 \times 10^{-5} \mathrm{M} \mathrm{H}_{2} \mathrm{O}_{2}$ & $\begin{array}{l}1.67 \times 10^{-5} \mathrm{M} \\
3.33 \times 10^{-5} \mathrm{M} \\
1.67 \times 10^{-4} \mathrm{M} \\
3.33 \times 10^{-4} \mathrm{M}\end{array}$ & $\begin{array}{l}66.5 \div 4.8 \\
67.8 \div 1.8 \\
73.9 \pm 3.2 \\
75.2 \div 1.9\end{array}$ & $\begin{array}{l}3.08 \pm 0.78 \\
3.61 \pm 1.11 \\
5.51 \pm 1.27 \\
6.01 \pm 1.64\end{array}$ \\
\hline $\begin{array}{l}X \text { ray } \\
X \text { ray }+ \text { catalase }\end{array}$ & $\begin{array}{l}(6500 \mathrm{rad} / \mathrm{min}) \\
(100 \text { units } / \mathrm{ml})\end{array}$ & $\begin{aligned} 44.0 & \doteq 6.1 \\
6.1 & \pm 0.1\end{aligned}$ & $\begin{array}{c}1.15 \pm 0.20 \\
\infty\end{array}$ \\
\hline
\end{tabular}

covery of luminescence began early after $\mathrm{H}_{2} \mathrm{O}_{2}$ treatment, but vigorous recovery did not begin until $\mathrm{H}_{2} \mathrm{O}_{2}$ concentrations fell to the micromolar level. The technique used may not stop all reactions with $\mathrm{H}_{2} \mathrm{O}_{2}$ after filtration and before iodide was added. This error would displace the $\mathrm{H}_{2} \mathrm{O}_{2}$ curve to the right of its position in fig. 3 .

\section{Discussion}

In former studies ${ }^{2}$ ), an X-ray dose of 6500 rad produced between 40 and $80 \%$ suppression of luminescence. Recovery began within seconds after exposure. The present study has shown that appropriate amounts of $\mathrm{H}_{2} \mathrm{O}_{2}$ 


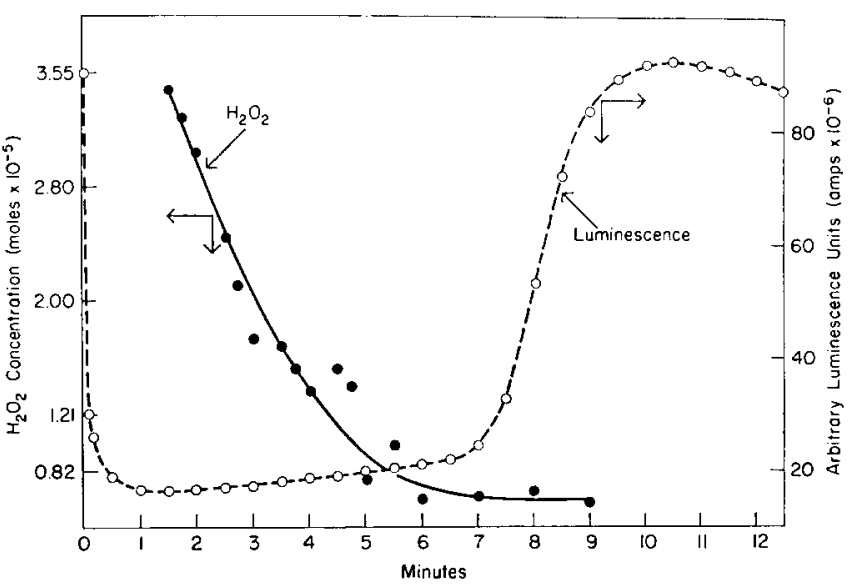

Fig. 3. The time-course of luminescence after $\mathrm{H}_{2} \mathrm{O}_{2}$ addition to luminous cell samples compared with the rate of destruction of $\mathrm{H}_{2} \mathrm{O}_{2}$ in similar samples.

mimic these radiation effects. For example, $1.5 \times 10^{-5} \mathrm{M} \mathrm{H}_{2} \mathrm{O}_{2}$ very closely matched the $\mathrm{X}$-ray effect and was roughly analogous to $8500 \mathrm{rad}$ (fig. $2 \mathrm{~A})^{12}$ ).

The difference between the X-ray dose of $6500 \mathrm{rad}$ and the $\mathrm{H}_{2} \mathrm{O}_{2}$ dose analogous to $8500 \mathrm{rad}$ needed for $75 \%$ suppression of luminescence is not significant because $\mathrm{X}$ rays produce $\mathrm{H}_{2} \mathrm{O}_{2}$ randomly throughout the irradiated volume at a finite rate while $\mathrm{H}_{2} \mathrm{O}_{2}$ is added to samples all at once and at least initially is all outside the cell membrane. Compare the initial rates of suppression in figs. 1 and 2 . Also, $\mathrm{X}$ rays undoubtedly produce a wider array of effects than does $\mathrm{H}_{2} \mathrm{O}_{2}$.

As expected, increased amounts of catalase produced the same effect as reduced amounts of $\mathrm{H}_{2} \mathrm{O}_{2}$ (figs. $2 \mathrm{~A}$ and $2 \mathrm{~B}$ ). Catalase added to cell suspensions prior to $\mathrm{X}$ irradiation completely obliterated the reversible suppression of luminescence (see fig. 1 and table 1). Further, since added catalase attenuated the effects of $\mathrm{H}_{2} \mathrm{O}_{2}$, the amounts of $\mathrm{H}_{2} \mathrm{O}_{2}$ added here overwhelmed endogenous catalase.

The hypotheses ${ }^{1}$ ) that radiation effects on luminescence are mediated by $\mathrm{H}_{2} \mathrm{O}_{2}$ and 2) that endogenous catalase activity protects this system to some extent, were tested by treating the cell samples with cyanide prior to the addition of $\mathrm{H}_{2} \mathrm{O}_{2}$. Fig. 2D shows that the results agree with the hypotheses since nearly micromolar concentrations of cyanide were measurably effective in enhancing the effects of $\mathrm{H}_{2} \mathrm{O}_{2}$. It can be inferred from these data that $\mathrm{H}_{2} \mathrm{O}_{2}$ actually produces its effects inside the cell. Cyanide added to cell suspensions prior to $\mathrm{X}$ irradiation produces effects similar to those described here $^{18}$ ). Since cyanide inhibits cytochrome as well as catalase 
activity, the mechanism by which cyanide sensitizes luminescence to $\mathrm{H}_{2} \mathrm{O}_{2}$ may involve more than just the inactivation of catalase.

The mechanism for the reversible suppression of luminescence by $\mathrm{X}$ rays or $\mathrm{H}_{2} \mathrm{O}_{2}$ is not known. However, it seems clear from fig. 3 that luminescence does not recover until the $\mathrm{H}_{2} \mathrm{O}_{2}$ concentration is significantly reduced. Since luminescence does recover, the biochemical target of peroxide oxidation must be under continuous production in some cellular pathway. We suggest three intermediates as likely peroxide targets: reduced nicotine adenine dinucleotide (NADH), reduced flavin mononucleotide $\mathrm{FMNH}_{2}$, and reduced luciferase. All these compounds are essential for bacterial luminescence and must be chemically reduced in sequence for steady-state luminescence ${ }^{19}$ ). According to our hypothesis, $\mathrm{H}_{2} \mathrm{O}_{2}$ added or produced by $\mathrm{X}$ rays reversibly oxidizes one or possibly all of these intermediates and suppresses luminescence.

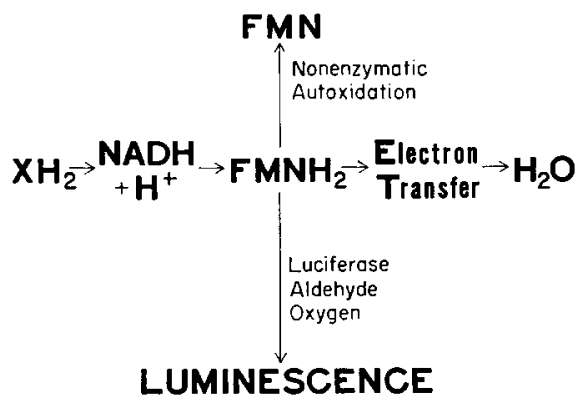

Fig. 4. The relation of various biochemical intermediates to luminescence and electron transport.

After $\mathrm{H}_{2} \mathrm{O}_{2}$ is hydrolized, luminescence recovers in response to the return to normal of substrate concentrations. The relation of these compounds to luminescence and electron transport is presented in fig. 4 which shows the central importance of reduced flavin mononucleotide. NAD reduction precedes while luciferase reduction follows the reduction of FMN.

Cyanide inhibits cytochrome oxidase and probably reduces competition for $\mathrm{NADH}$ and $\mathrm{FMNH}_{2}$. This might explain why the time required for maximum suppression by $\mathrm{H}_{2} \mathrm{O}_{2}$ is increased by cyanide (fig. 2D). Also, cells suspended in growth medium instead of non-nutrient saline or cells in buffered saline with micromolar glucose do not exhibit reversible suppression of luminescence by $X$ rays $^{18}$ ). When luminescence of a sample is low, recovery is neither as rapid nor as complete as in samples with bright luminescence. For example, the recovery rate for the bright samples (fig. 2A) is about 3.5 times faster than for dim samples (fig. 2B). 
Failure of luminescence to return to the pre-treatment level may be due to cell death or enzyme denaturation ${ }^{11}$ ) caused by momentarily high concentrations of $\mathrm{H}_{2} \mathrm{O}_{2}$. Experiments are being designed to add $\mathrm{H}_{2} \mathrm{O}_{2}$ at various rates to match irradiation experiments.

These results show that $\mathrm{H}_{2} \mathrm{O}_{2}$ does mimic radiation effects. Further, this radiomimetic effect is immediate and reversible. If measurements are not made continuously throughout the treatment, reversible events may not be seen. Perhaps some attempts to show radiomimetic effects have failed because the measurements were not made until these effects had disappeared.

\section{Acknowledgements}

The critical review of Drs. G. Hoyt Whipple and Isadore A. Bernstein is acknowledged and appreciated.

\section{References}

1) C. H. Burns, A. P. Jacobson and G. H. Whipple, Radiation Res. 29 (1965) 494.

2) A. P. Jacobson, J. Luminescence 3 (1970-1971) 203.

3) H. Fricke, J. Chem. Phys. 2 (1934) 556.

4) P. Bonet-Maury and M. Lefort, Nature 162 (1948) 381.

5) P. Bonet-Maury and M. Lefort, J. Chim. Phys. 47 (1950) 179.

6) H. Fricke, J. Chem. Phys. 3 (1935) 364.

7) E. S. G. Barron, L. Seki and P. Johnson, Arch. Biochem. Biophys, 41 (1952) 188.

8) H. I. Adler, Radiation Res. Suppl. 3 (1963) 110.

9) A. M. Kuzin, in: Radiation Biochemistry (Israel Program for Scientific Translations Ltd., Jerusalem, 1964) p. 24.

10) Z. M. Bacq and J. Moutschen, Compt. Rend. Soc. Biol. Belg. 150 (1956) 2262.

11) E. D. Willis, Biochem. Pharmacol. 2 (1959) 276.

12) M. Frilley, Brit. J. Radiol. Suppl. 1 (1947) 50.

13) C. H. Burns, A. D. Nevill and G. H. Whipple, Anal. Biochem. 5 (1963) 393.

14) D. J. Savage, Analyst 76 (1951) 224.

15) Sigma Chemical Co. catalog 1969, p. 70 . One Sigma unit (SU) will decompose $1 \mu \mathrm{M}$ $\mathrm{H}_{2} \mathrm{O}_{2}$ per minute at $\mathrm{pH} 7.0$ and $25^{\circ} \mathrm{C}$, while the $\mathrm{H}_{2} \mathrm{O}_{2}$ concentration falls from 10.3 to $9.2 \mu \mathrm{M}$ per milliliter of reaction mixture. The rate of disappearance of $\mathrm{H}_{2} \mathrm{O}_{2}$ is followed by observing the rate of decrease in optical density at $240 \mathrm{~nm}$.

16) $\mathrm{H}_{2} \mathrm{O}_{2}$ is diluted to $100 \mathrm{ml}$ with distilled water in a volumetric flask. Twenty $\mathrm{ml}$ of this solution is treated with $50 \mathrm{ml}$ of dilute $\mathrm{H}_{2} \mathrm{SO}_{4}$ (S.G. 1.110-1.114) and diluted further with $50 \mathrm{ml}$ distilled water. This solution is titrated with $0.1 \mathrm{~N} \mathrm{KMnO}_{4}$ to stable red color. Each milliliter of $\mathrm{KMnO}_{4}$ equals $1.7008 \mathrm{mg} \mathrm{H}_{2} \mathrm{O}_{2}$.

17) D. Keilin and E. F. Hartree, Proc. Roy. Soc. (London) B 121 (1936) 173.

18) A. P. Jacobson, unpublished data.

19) J. W. Hastings, W. H. Riley, and J. Massa, J. Biol. Chem, 240 (1965) 1473. 